J. Perinat. Med. 16 (1988) 315

\title{
Assessment of local area network based on the microcomputer system for data processing of perinatal medical information
}

\author{
Hiromasa Nakahara, Takashi Koyanagi, Kenzo Hirose, and Hitoo Nakano \\ Department of Gynecology and Obstetrics, Faculty of Medicine, Kyushu Univer- \\ sity, Japan
}

\section{Introduction}

With recent advance in technology, we can see, more than ever before, the importance of interconnecting social activity through the exchange of information. It is the computer system, as having rapidly progressed in recent years, which has come to play the leading role of managing the information. In the medical field as well, treating information through the use of electronic data-processing is desired, because conventional medical charts are overflowing with increasing data.

From this point of view, we developed a microcomputer-based local area network (LAN) system for controlling and storing information of perinatal medicine [3]. This system has been in a clinical test run since June, 1986. The results obtained are herein reported, and also given is an assessment of whether or not this system will be useful for future perinatal medicine.

\section{Material and methods}

The hard-and soft-ware configurations of our LAN system were previously reported in detail elsewhere [3]. Briefly six microcomputer terminals (NEC 9801 M2) (two in the outpatient department, one in the obstetric ward, one in the delivery room, one in the neonatal room and the last one in the ultrasound examination ward) were linked in star formation to a central control unit (INTEC AceMate B-28 JWL4). With the use of this system, all members of the medical staff can enter data, obtained during an examination period, anywhere and anytime into a microcomputer terminal. The data is processed in a real-time manner and, if

\section{Curriculum vitae}

Hiromasa NaKaHARA was born in Yamaguchi, Japan, in 1955, and was graduated from Kyushu University in 1980. He completed postgraduate training in the Department of Gynecology and Obstetrics, Faculty of Medicine, Kyushu University and Saga Medical School. He presently specializes in obstetrics and

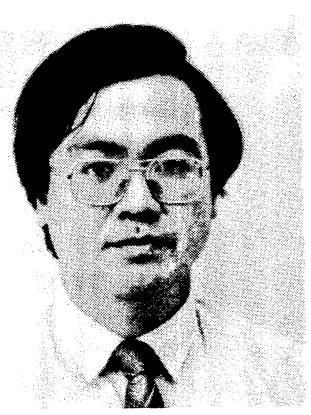
gynecology at Kyushu University in Fukuoka, Japan. His main fields of interest include developmental physiology of human fetuses and the computerization of medical information.

necessary, can be fed back on the TV-display of the nearest terminal, together with previously entered information on the individual patient.

The items listed in table I were assessed in this study in relation to feasibility in obstetric care.

\section{Results}

\subsection{Assessment of system activity}

System maintenance: Annual maintenance for the hard-ware system generally required about 5,800 U.S. dollars; respectively, 3,800 dollars for regular inspection of the system and approximately 2,000 dollars for expendable supplies such as floppy disks and printer paper. The electronic power necessary for operating the entire system was 2,400 
Table I. The items of assessment for the LAN system

1. Assessment of system activity

System maintenance

System failure

2. Assessment of patient-machine interface

3. Assessment of doctor-machine interface

Operative ability with regard to man-machine

interface

Time performance

Application of data base

$\mathrm{w} / \mathrm{hr}$. corresponding to the cost of 1,200 dollars per year. This system did not require any control variations related to the environmental conditions in terms of temperature and humidity.

System failure: During the ten-month testing period, major system failures occurred twice in the central control unit of the system: one was due to a broken wire and the other occurred due to a breakdown in the diskboard. It took from 6 to 12 hours to find these causes and repair the system. System failures at the microcomputer terminals were mainly caused by mis-operation. In these cases, the microcomputer systems needed only to be reactivated by turning on the reset switch. Although mechanical troubles such as paper jams occurred occasionally, other printers could be immediately backed up for substitutive use until the problems were rectified. Therefore, during a temporary system failure, few data were lost. After the system was repaired, the lost data were put back into the system in a batch manner.

\subsection{Patient-machine interface}

Pregnant women have reached a level of better understanding of the chronological conditions of themselves and their fetuses with the aid of timerelated graphs displayed on the microcomputer TV screen. The problem using these computers created was that the doctor was restricted to spending more time operating the computer system. This, thereby, led to a decrease in the time when doctor communicated with the patient in a face-to-face interview.

\subsection{Doctor-machine interface}

Operative ability with regard to man-machine interface: Prior to actually using the LAN system in obstetric practice, medical staff training about the clinical system took only one-hour using a simple operation manual. After this one-hour training session, the staff could easily accustom themselves to operating the system for regular clinical activities. Although, at the beginning of test run, typing-related errors were frequently found to cause system breakdowns, they decreased, as the doctors became more familiar with operation of this system. People without computer experience felt it was difficult to enter a patient's name and address, etc. in Japanese. In regard to this problem, a paramedical person assisted in booking a patient ID into the LAN system on the first visit of every outpatient.

Time performance: As for response time, it took as much as 3 seconds to change from one format to the next on the TV screen, and as much as 5 to 10 seconds to display time-tables and timerelated graphs. Input operation of routine work in the different wards required a range of time from 5 to 10 minutes per case in the output department and the obstetric ward, and from 10 to 15 minutes per case in the delivery ward (table II).

Table II. Assessment of time-performance

1. Input operation

Daily work

in outpatient department $5-10$ minutes/case

in obstetric ward $\quad 5-10$ minutes/case

in delivery ward $\quad 10-15$ minutes/case

2. Output operation

Print out daily summary admission, delivery and discharge summaries list of high risk patients

2 minutes/case 5-10 minutes/case 10-20 minutes

When attempting to output a set of summary charts, regarding the records from the outpatient care divisions through the admission to the discharge divisions, it took 5-10 minutes. This summary process included making an output format in the central processing unit, transferring the data in the arrangement of this format to the buffer of the printer, and finally printing out these data on a sheet. In addition, it took $10-20$ minutes to retrieve data-base on command, for examples, compiling a list of high risk patients and thereafter printing this list. 
Application of data base: In this system, one could make up data in a given set of required forms which could then be transferred into either the individual microcomputer systems or the large general purpose computer system of Kyushu University for various kinds of study of statistical analysis and simulation experiments. Finding these forms required an understanding of the codes which are explained in the dictionary management subsystem. Long-term experience was required to operate the central control unit of this system efficiently.

\section{Discussion}

Medical care is basically dependent on the close interrelation between the doctor and the patient. After collecting data from a patient by inquiry, physical examinations and laboratory examinations, the doctor makes a diagnosis and prescribes the appropriate treatment for the individual patient. Until now, medical charts have been conventionally used as the information medium. They are inconvenient and difficult to use in attempting to make an assessment of large scale data: e.g. an analysis of the long-term chronology of perinatal death rates. For this purpose, data needs to be under promptly accessable management and storing conditions. This leads the way to introduce the computer system as a manner of controlling medical information [1-7].

In line with this thought, we devised a perinatal information management system by means of the LAN system, and, on the basis of the ten-month test run in this paper, in regard to applicability between doctor, patient and machine interfaces.

A total of 7,000 U.S. dollars for the system maintenance was equivalent to a cost of 9-10 dollars/ year per individual woman, which was cheaper than that of 12.5 dollars reported by STUDNEY et al. [5]. This is due to the fact that no additional personnel was needed except for one paramedical person who assited in entering data in the system, and also, due to the low cost-performance for hard-ware system maintenance. Since the two major system failures noted have been caused by lack of careful maintenance, these can be avoided by the establishment of a continuous and close checking system. It is superior in this system that the system breakdowns limited to the terminal microcomputers have no influence on other terminals nor the central control unit.

The time related graph and time table were indeed useful for the patients to understand their personal conditions. Because the doctors were concentrating on machine operation, the patients felt less communication with doctor than before computerization was installed. To overcome this difficulty, we are now thinking of a way to up-grade the hard-ware system so as to speed-up the entering and processing of data.

As for doctor machine interface, the entire medical staff could operate the terminal microcomputer system without special training. This is possibly due to the simplification of the procedures in only using numeric keys. Input operation took $20-$ $30 \%$ more time than writing on the charts. This is derived from the fact that more items must be input than before and because of the time loss for scrolling the TV-display. However, as stored database contains almost all of the information used in perinatal medicine and is able to be easily accessed and processed, the medical staff gains a large profit from using this system.

From the assessment based on the results of test run, our LAN system was found to be an extensible protomodel for application to future perinatal medicine.

\section{Summary}

In order to control perinatal medical information, we developed a microcomputer-based local area network. This system has been in practical operation since June, 1986. We have assessed this system with regard to both patient-machine and doctor-machine interfaces. Consequently, although input operation took $20-30 \%$ longer

per individual patient than before, it was more feasible for medical staff to access and retrieve the data in a real-time manner. When tested in a ten month period, this system was found to be a prototype applicable for further extending the management of the entire scope of perinatal medical information.

Keywords: Local area network (LAN), man-machine interface, microcomputer system, perinatal medical information, system assessment. 


\section{Zusammenfassung}

Bewertung eines mikrocomputergestützten lokalen Netzwerkes zur Verarbeitung perinatologischer Daten

Um perinatologische Daten speichern und verarbeiten zu können, entwickelten wir ein mikrocomputergestütztes lokales Netzwerk. Dieses System ist seit Juni 86 im klinischen Einsatz. Dabei prüften wir das System im Hinblick auf seine Eignung im Zusammenspiel zwischen Arzt, Patient und Maschine. Zum Unterhalt des Systems war eine Gesamtsumme von 7000 US-Dollars erforderlich, was einen Kostenaufwand von 9-10 US-Dollars pro Jahr pro Schwangerer entspricht. Trotz einiger gröBerer und kleinerer Systemfehler gingen nur wenige $\mathrm{Da}$ ten verloren, und die klinische Praxis wurde nicht we- sentlich beeinträchtigt. Was die Verbindung von Mensch und Maschine betrifft, erwiesen sich Zeitkurven und Zeittafeln für die Patientin als nützlich zum Verständnis sowohl der eigenen zeitlichen Zustandsverläufe als auch der ihrer Feten. In bezug auf die Verbindung ArztMaschine wurde, obwohl die Eingabe $20-30 \% \mathrm{mehr}$ Zeit pro Patient in Anspruch nahm, der Zugriff auf die Daten und das Wiederauffinden in Echtzeit für das medizinische Personal zunehmend leichter zu handhaben. Nach einem 10-monatigen Test erwies sich dieses System als ausbaufähiger Prototyp für die weitere Anwendung in der perinatalen Medizin.

Schlüsselwörter: Lokales Netzwerk, Mensch-Maschine, Mikrocomputersystem, perinatologische Daten, Systembewertung.

\section{Résumé}

Évaluation d'un réseau d'aires locales fonde sur un système de micro-ordinateur pour le traitement des données d'information médicale périnatale

Nous avons développé un réseau d'aires locales sur micro-ordinateur afin de stocker et de traiter l'information médicale périnatale. Le systême a été utilisé en pratique clinique depuis Juin 1986. Dans cet article, nous évaluons ce systême en ce qui concerne son applicabilité entre médecins, patients et inferfaces machines. Pour la maintenance du systême, logiquement, le coût total nécessaire a été de 7000 dollars, ce qui équivaut à un coût de 9,10 dollars par an et pour chaque femme enceinte. Il n'y a pas eu d'influence majeure sur la pratique clinicque et peu de données ont été perdues même si sont apparues quelques défaillances mineures ou majeures du systême. Pour l'interface machine-patiente, les courbes en fonction du temps ainsi que les tables ont été utiles pour la compréhension de la chronologie par les patientes pour elles-mêmes et pour leurs fœtus. En ce qui concerne l'interface machine-médicin même si les opérations de saisies prennent 20 à $30 \%$ de plus pour chaque patient, l'accessibilité et le retour en arrière pour les données en temps réel, sont devenus plus praticables pour l'équipe médicale. Testé sur une période de 10 mois, on a trouvé que ce systême est un prototype à diffuser dans son application à la médecine périnatale future.

Mots-clés: Information d'un systême, information médicale périnatale, interface machine-homme, réseau d'aires locales, systême de micro-ordinateurs.

Acknowledgements: This study was funded for the purpose of joint research between Kyushu University and Industry (INTEC Incorporation), and supported by a Grant-in-Aid for Scientific Research (No. 60480371), Japan.

\section{References}

[1] LILFORD RJ, T CHARD: Microcomputer in antenatal care, a feasibility study on the booking interview. Br Med J 283 (1981) 533

[2] Maresh M, AM Dawson, RW Beard: Assessment of an on-line computerized perinatal data collection and information system. Br J Obstet Gynaecol 93 (1986) 1239

[3] Nakahara H, K Koyanagi, H Teraoka, H SंHIMOKAWA, K HARA, H NAKANO: Microcomputerbased local area network system for controlling information on perinatal medicine. Int $\mathrm{J}$ Biomed Comput 21 (1987) (83)

[4] Stead WW, RG Brame, WE Hammand, FR JelovSEK, EH ESTES, RF PARKER: A computerized obstetric medical record. Obstet Gynecol 49 (1977) 502
[5] Studney DR, JB Adames, A Gorbach, FS GuenTHNER, MM MORGAN, GO BARNETT: A computerized perinatal record. Obstet Gynecol 50 (1977) 82

[6] Tuck CS, A Cundy, H Wagman, M Usherwood, $M$ Thomas: The use of computer in an obstetric department. Br J Obstet Gynaecol 83 (1976) 97

[7] WAGNER JE, WJ WarReNER, SA BLADFIELD, PL FORRAR, LG MOREHOUSE: A computer based system for collection, storage, retrieval and reporting accession information in a veterinary medical diagnostic laboratory. Comput Biol Med 14 (1984) 325

Takashi Koyanagi, M.D.

Department of Gynecology and Obstetrics

Faculty of Medicine, Kyusyu University 60

Maidashi 3-1-1, Higashi-ku

Fukuoka 812, Japan 